\title{
Studies of Parietal Cell Antibody in Pernicious Anemia*
}

\author{
Graham H. Jeffries $†$ and Marvin H. Sleisenger with the tech nical \\ assistance OF Sue Margolis \\ (From the Department of Medicine, Division of Gastroenterology, Cornell University Medical \\ College, New York, N. Y.)
}

The etiology of atrophic gastritis, the primary pathologic lesion in Addisonian pernicious anemia, has not been established. It has been suggested, however, on the basis of indirect evidence, that the mucosal glands in the body and fundus of the stomach may be destroyed by an autoimmune process (2). Antibodies to gastric intrinsic factor (3-6) and to gastric parietal cell cytoplasmic antigen (2, 7-9) may be present in sera from patients with pernicious anemia. Furthermore, treatment of pernicious anemia patients with prednisolone may result in a regeneration of chief and parietal cells in the gastric mucosa, with secretion of acid and intrinsic factor and improvement in vitamin $B_{12}$ absorption $(10,11)$. This corticosteroid effect may result from the suppression of immunologic processes that destroy parenchymal cells in the gastric mucosa.

The evidence that has been cited in support of an autoimmune etiology in pernicious anemia does not exclude the alternative hypothesis that immunologic mechanisms play no etiologic role in this disease and that circulating antibodies reactive with gastric mucosal antigens are merely the result of previous gastric mucosal injury $(12,13)$. The recovery of the gastric mucosa during prednisolone therapy could be explained alternatively by a stimulation of mucosal cell regeneration.

Previous studies have shown that parietal cell

* Submitted for publication June 23, 1965; accepted September 7, 1965.

Supported by research grant CA 09386 from the National Cancer Institute, U. S. Public Health Service, and in part by a grant from the John A. Hartford Foundation. Presented in part at the annual meeting of the American Gastroenterological Association, Montreal, Canada, May 28, 1965 (1).

$\dagger$ Recipient of U. S. Public Health Service Research Career Development award: 5-K3-AM-14, 153 from the National Institute of Arthritis and Metabolic Diseases. Address requests for reprints to Dr. Graham H. Jeffries, 525 East 68th St., New York, N. Y. 10021. antibody, present almost exclusively in sera from patients with atrophic gastritis or pernicious anemia, reacts with an antigen or antigens in the cytoplasm of gastric parietal cells and is unreactive with antigens in other tissues $(2,8)$. The distribution of this antibody in the immunoglobulin fractions of serum has not been determined, and the titer of antibody in serum has been measured only by a complement fixation reaction using crude gastric mucosal extracts as antigen $(2,7,14)$.

In the present experiments, sera and gastric juices from patients with pernicious anemia were tested for the presence of parietal cell antibody by an immunofluorescent method. The titer of antibody in each specimen was measured, and its distribution in the specific immunoglobulin fractions was determined. The distribution of immunoglobulins in frozen sections of gastric mucosal biopsies from patients with pernicious anemia was also studied by immunofluorescent staining. Parietal cell antibody, present in sera from $86 \%$ of patients with pernicious anemia, was characterized for the first time as a $\gamma \mathrm{G}$-globulin and was also identified in gastric juice.

\section{Methods}

Sera and gastric juice samples and gastric mucosal biopsies were obtained from patients with Addisonian pernicious anemia. These patients had suffered from a megaloblastic anemia that responded to parenteral vitamin $\mathrm{B}_{12}$ therapy, had subnormal vitamin $\mathrm{B}_{12}$ absorption that was corrected with intrinsic factor, and secreted no acid during augmented histamine stimulation (15).

Sera were stored at $-20^{\circ} \mathrm{C}$ without added preservative for periods up to 4 years. Gastric juice was obtained by intermittent hand suction through a nasogastric tube. Both fasting and stimulated gastric secretions (histamine acid phosphate, $0.04 \mathrm{mg}$ per $\mathrm{kg}$ subcutaneously, or betazole hydrochloride, $100 \mathrm{mg}$ subcutaneously) were collected and stored at $-20^{\circ} \mathrm{C}$. Gastric biopsy specimens were obtained from the body and fundus of the stomach through a peroral hydraulic multiple biopsy tube (16) positioned fluoroscopically. Paraffin sections of formalinfixed tissue were stained with hematoxylin and eosin for 
routine light microscopic examination. For immunofluorescent studies, the gastric biopsy specimens were immediately embedded in $7.5 \%$ gelatin (17), frozen in an acetone-dry ice bath at $-70^{\circ} \mathrm{C}$, and stored at $-20^{\circ} \mathrm{C}$ in sealed containers to prevent dehydration.

Goat antisera to human immunoglobulins $(\gamma \mathrm{G}-, \gamma \mathrm{A}-$, and $\gamma \mathrm{M}$-globulins, respectively) were obtained commercially. 1 Each antiserum, tested by immunoelectrophoresis and by double diffusion in agar, gave a single precipitin band against fresh normal human serum. Fluorescein conjugates of each antiserum were prepared by a method that has been previously described (18).

Immunofluorescent demonstration of parietal cell antibody in serum. A modification of the methods described previously was used $(2,8,19)$. Sections $6 \mu$ in thickness were cut from fresh-frozen rat stomach in an International-Harris cryostat at $-20^{\circ} \mathrm{C}$, placed on glass microscope slides, air dried, and fixed in acetone for 1 minute at room temperature. After fixation, the slides were air dried at room temperature and used within 24 hours.

The parietal cell antibody test was carried out as follows. The sections of rat gastric mucosa were washed for 5 minutes in phosphate-buffered saline (PBS) at $\mathrm{pH} 7.4$, incubated for 30 minutes at $37^{\circ} \mathrm{C}$ with pernicious anemia serum diluted $1 / 4$ with $P B S$, washed in three changes of PBS for 15 minutes, incubated for 30 minutes at room temperature with fluoresceinated antihuman $\gamma \mathrm{G}$-globulin antiserum, and finally washed in three changes of PBS for 30 minutes. The sections were then mounted in $0.025 \mathrm{M}, \mathrm{pH} 7.4$ phosphate-buffered glycerol and covered with a glass cover slip.

The slides were studied within 6 hours of staining with a Zeiss fluorescence microscope, using an Osram-200 mer-

${ }^{1}$ Hyland Laboratories, Los Angeles, Calif. cury arc, one BG12 exciter filter, a dark field condenser, and a Zeiss no. 53 barrier filter. Representative colored photomicrographs were obtained with Anscochrome T/200 tungsten film.

Sections of rat esophagus, small intestine, pancreas, liver, and kidney were also used in preliminary control studies to confirm the specificity of the immunofluorescent reaction between parietal cell antibody and gastric parietal cell cytoplasm.

Measurement of the titer of parietal cell antibody in serum. Serial dilutions of each serum $(1 / 4,1 / 8, \ldots$ to $1 / 512$ ) were used in these parietal cell antibody tests. A single pool of fluoresceinated antihuman $\gamma \mathrm{G}$-globulin antiserum was used to measure parietal cell antibody titers; this ensured that there was no variation in parietal cell immunofluorescence due to variations in the titer of the fluoresceinated antibody. The titer of parietal cell antibody in each serum specimen was expressed as the lowest concentration of diluted serum at which parietal cell immunofluorescence could be detected.

Determination of the distribution of parietal cell antibody in the immunoglobulin fractions of serum. Sections of rat gastric mucosa, preincubated as above with pernicious anemia serum ( $1 / 4$ dilution), were incubated with fluoresceinated antisera to $\gamma \mathrm{G}-, \gamma \mathrm{A}-$, and $\gamma \mathrm{M}$-globulin, respectively. The specificity of parietal cell staining by each fluoresceinated antiserum was tested either by exposing sections to nonfluoresceinated antiserum before the incubation with fluoresceinated antiserum, or in the case of fluoresceinated anti- $\gamma \mathrm{A}-$ globulin antiserum, by direct absorption of the antiserum with purified $\gamma \mathrm{G}$-globulin. This purified $\gamma \mathrm{G}$-globulin was prepared from normal serum by precipitation with $18 \%$ sodium sulfate and purified by column chromatography on DEAE-cellulose with $0.1 \mathrm{M}, \mathrm{pH} 7.0$ phosphate buffer. It gave a single

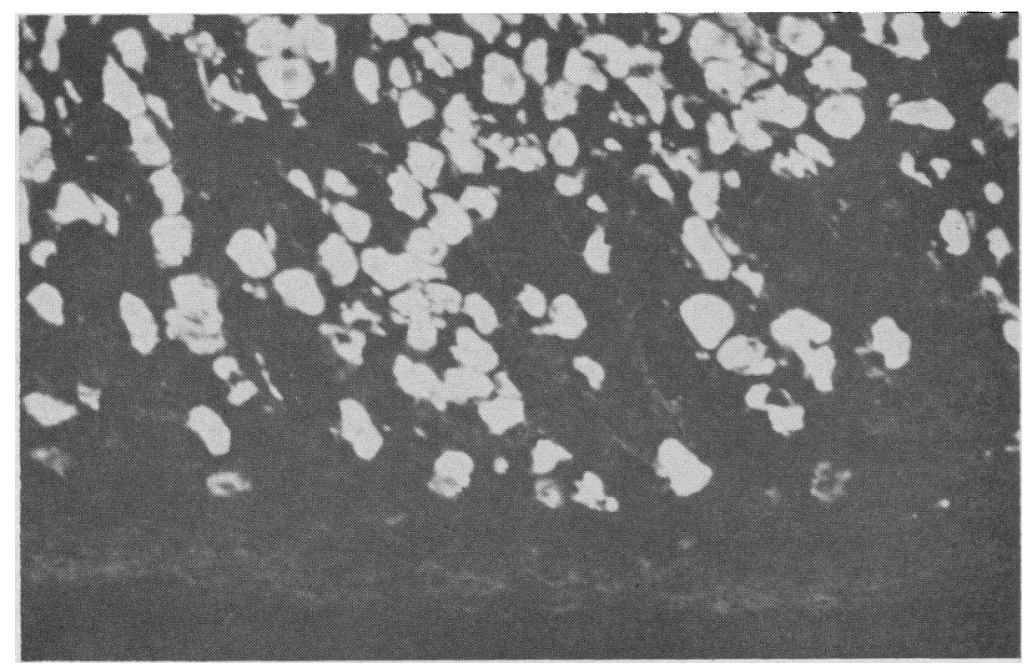

Fig. 1. Parietal Cell immunofluorescence. A frozen section of rat gastric mucosa was incubated with pernicious anemia serum (diluted 1/4 with phosphate-buffered saline) followed by fluoresceinated antiserum to $\gamma$ G-globulin. Magnification $\times 375$. 


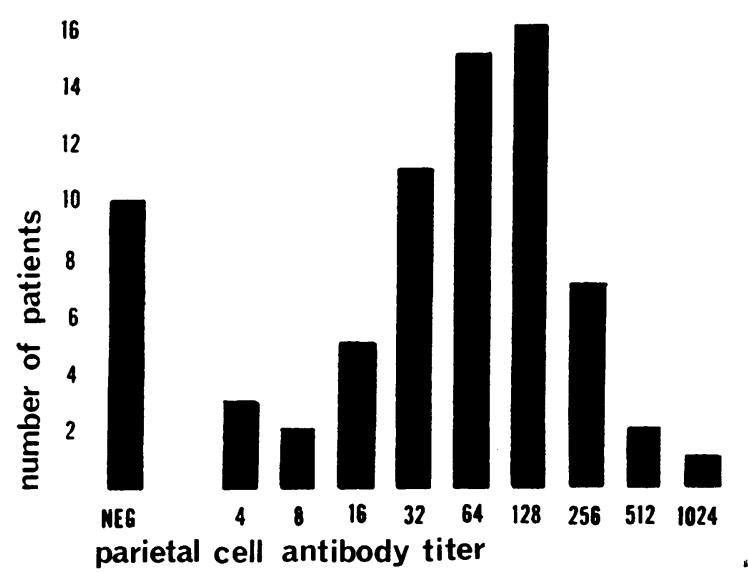

Fig. 2. The titers of PARIETAL CELL ANTIBOdY IN SERA FROM PATIENTS WITH PERNICIOUS ANEMIA.

precipitin band on immunoelectrophoresis with antihuman immunoglobulin antiserum ${ }^{1}$ and a corresponding precipitin band with antihuman $\gamma \mathrm{G}$-globulin antiserum, but did not react with antihuman $\gamma \mathrm{A}$-globulin antiserum.

Demonstration of parietal cell antibody in gastric juice. Gastric juice from six patients with pernicious anemia was tested for parietal cell antibody. Frozen sections of rat gastric mucosa were incubated with dilutions of gastric juice in $\operatorname{PBS}(1 / 1,1 / 4, \ldots 1 / 64)$ and then incubated with fluoresceinated anti- $\gamma \mathrm{G}$-globulin or anti- $\gamma \mathrm{A}$ globulin antisera, respectively. Gastric juice contaminated with blood was not tested.

Test for immunoglobulins and parietal cell antibody in gastric mucosal biopsies from patients with pernicious anemia. To determine the tissue distribution of immunoglobulins, $6-\mu$ frozen sections of gastric mucosal biopsies from patients with pernicious anemia were incubated with fluoresceinated antihuman $\gamma \mathrm{G}-, \gamma \mathrm{A}-$, and $\gamma \mathrm{M}$-globulin antisera, respectively. Both acetone- and alcohol-fixed and unfixed sections were examined. A 30 -minute period of incubation with fluoresceinated antiserum at room temperature was followed by a 30 -minute wash in three changes in PBS.

To test for parietal cell antibody in gastric mucosal biopsies from patients with pernicious anemia, biopsy specimens that had been stored at $-20^{\circ} \mathrm{C}$ were thawed and homogenized in $0.5 \mathrm{ml}$ of PBS in a Potter-Elvehjem tissue grinder. The tissue extract was tested for parietal cell antibody by the method described for serum.

\section{Results}

Of 72 sera from patients with pernicious anemia tested for parietal cell antibody, $62(86 \%)$ gave a positive reaction. Immunofluorescence was localized in the cytoplasm of gastric parietal cells (Figure 1). These sera gave no immunofluorescent reaction when tested with sections of rat esophagus, small intestine, pancreas, liver, or kidney.
Measurement of parietal cell antibody titer in serum. When positive sera were tested at serial dilutions, there was a progressive diminution in parietal cell immunofluorescence. The serum titer of parietal cell antibody is recorded as the highest dilution of serum at which immunofluorescence could be detected. When negative sera were tested in serial dilutions, no specific parietal cell immunofluorescence could be detected at any dilution. To establish the reproducibility of the method, duplicate analyses of parietal cell antibody titer were carried out on 20 sera at intervals of 4 to 6 weeks. The same fluoresceinated $\gamma \mathrm{G}$-globulin antiserum was used in each of these analyses, but sections of gastric mucosa from different rats were utilized. The parietal cell antibody titer of each serum sample did not vary in these duplicate analyses.

The titers of parietal cell antibody measured in sera from 72 patients with pernicious anemia are shown in Figure 2. These titers ranged from 0 to $1 / 1,024$ with a peak frequency at $1 / 64$ and $1 / 128$. The titer of parietal cell antibody in sera from patients with pernicious anemia was not related to the duration of their disease and did not vary in samples obtained from individual patients during a period of up to 4 years. In Figure 3, the titer of parietal cell antibody in serum from each patient with pernicious anemia is plotted against

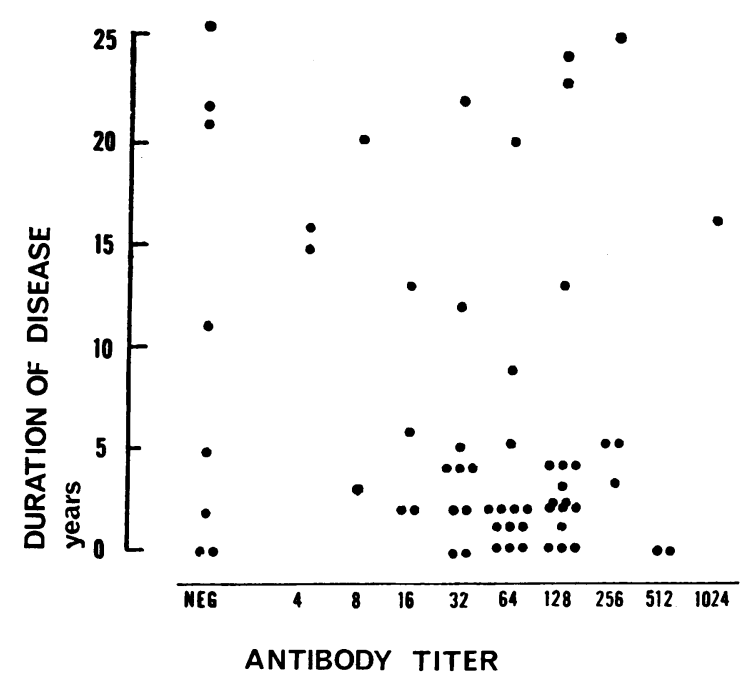

Fig. 3. The Relationship between the titer of PARIETAL CELL ANTIBODY IN SERUM AND THE DURATION OF PERNICIOUS ANEMIA. Antibody titers were unrelated to the duration of anemia. 

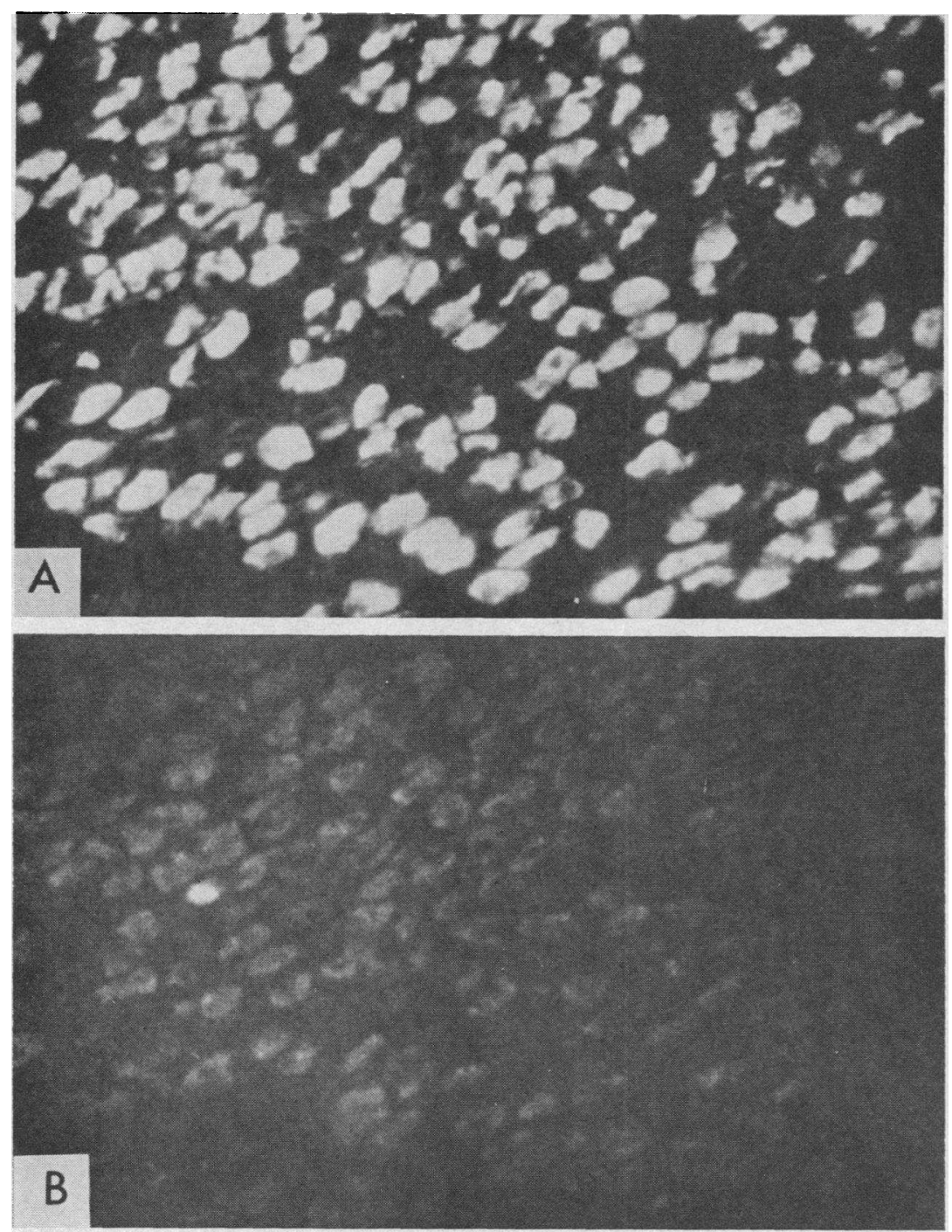

Fig. 4. Parietal cell immunofluorescence using antisera to $\gamma$ A-globulin. The immunofluorescence of parietal cells in mucosal sections incubated with pernicious anemia serum and fluoresceinated antiserum to $\gamma \mathrm{A}$-globulin (A) was almost completely inhibited when the antiserum was absorbed with purified $\gamma \mathrm{G}$ globulin (B). Magnification $\times 375$.

the time in years since the diagnosis of pernicious anemia was established.

The distribution of parietal cell antibody in the immunoglobulin fractions of serum. Pernicious anemia sera that gave a positive parietal cell immunofluorescent reaction when tested with fluoresceinated antiserum to $\gamma \mathrm{G}$-globulin were also positive when tested with fluoresceinated $\gamma \mathrm{A}$-globulin antiserum, but were negative in tests with fluoresceinated $\gamma \mathrm{M}$-globulin antiserum. Sera that were negative in tests using fluoresceinated $\gamma \mathrm{G}$-globulin antiserum were also negative in tests using other antisera. In testing for the specificity of these immunofluorescent reactions, it was shown that parietal cell immunofluorescence was inhibited when sections were preincubated with the respective unconjugated antisera. Parietal cell immunofluorescence in tests using fluoresceinated antiserum to $\gamma \mathrm{A}$-globulin was almost completely inhibited by direct absorption of the antiserum with purified $\gamma$ G-globulin (Figure 4). This result indicates that the parietal cell immunofluorescent re- 
action with fluoresceinated antisera to $\gamma \mathrm{A}$-globulin may result mainly from the cross-reaction of this antiserum with $\gamma \mathrm{G}$-globulin. From these observations we concluded that parietal cell antibody resides predominantly in the $\gamma \mathrm{G}$-globulin fraction of pernicious anemia sera, although minor amounts may be present in the $\gamma \mathrm{A}$-globulin fraction.

Demonstration of parietal cell antibody in gastric juice from patients with pernicious anemia. Parietal cell antibody was detected in the achlorhydric gastric juice from six patients with pernicious anemia, both during fasting and when stimulated. The titer of antibody in each gastric juice was considerably less than that present in the patient's serum (Table I), and tests using fluoresceinated antisera to $\gamma \mathrm{G}$ - and $\gamma \mathrm{A}$-globulins indicated that the antibody was a $\gamma \mathrm{G}$-globulin as in the serum.

Identification of immunoglobulins and parietal cell antibody in gastric mucosal biopsies from patients with pernicious anemia. The distribution of immunoglobulins was studied in frozen sections of gastric mucosal biopsies from three patients with pernicious anemia. Incubation of these sections with fluoresceinated antisera to $\gamma \mathrm{G}-, \gamma \mathrm{A}$-, and $\gamma \mathrm{M}$ globulins produced tissue fluorescence that was localized in the lamina propria of the mucosa and particularly concentrated in mononuclear cells. This was best seen in acetone-fixed sections (Figures 5). In hematoxylin and eosin stained sections, both lymphocytes and plasma cells were identified in the lamina propria. The specificity of the immunofluorescent staining with antisera to $\gamma \mathrm{G}$ - and $\gamma \mathrm{A}$-globulins was confirmed by preincubating mucosal sections with unconjugated antisera. Staining with fluoresceinated antiserum to $\gamma$ G-globulin was inhibited by prior incubation with unconjugated $\gamma \mathrm{G}$-globulin antiserum, but was not inhibited by unconjugated $\gamma \mathrm{A}$-globulin antiserum. Conversely, staining with fluoresceinated antiserum to $\gamma \mathrm{A}$-globulin was inhibited by homologous unconjugated antiserum, but was not inhibited by unconjugated $\gamma \mathrm{G}$-globulin antiserum. Both $\gamma \mathrm{G}$ and $\gamma \mathrm{A}$-globulins were detected in many of the infiltrating cells (Figure $5 \mathrm{~A}, \mathrm{~B}$ ), whereas $\gamma \mathrm{M}$ globulin was seen in only a few cells (Figure $5 \mathrm{C}$ ).

Gastric mucosal biopsies from five patients with pernicious anemia were homogenized in PBS, and the tissue extract was tested for parietal cell antibody. Sera from each of these patients contained

\begin{tabular}{ccc} 
TABLE I & $\begin{array}{c}\text { Titers of parietal cell antibody in } \\
\text { serum and gastric juice }\end{array}$ \\
\hline \hline & Serum & $\begin{array}{c}\text { Gastric } \\
\text { juice } \\
\text { titer }\end{array}$ \\
\hline Patient & 32 & 4 \\
& 64 & 4 \\
2 & 128 & 16 \\
3 & 256 & 16 \\
4 & 256 & 8 \\
5 & 512 & 8 \\
6 & & \\
\hline
\end{tabular}

antibody. No parietal cell antibody could be detected in these extracts of gastric mucosa.

\section{Discussion}

Antibodies reactive with parietal cell cytoplasm in an immunofluorescent test using rat gastric mucosa were detected in sera for $86 \%$ of 72 patients with adult pernicious anemia. This incidence of antibody corresponds to that reported in the literature $(2,14,19,20)$.

The titer of parietal cell antibody has been measured with serial dilutions of serum in the immunofluorescent test, and reproducible results have been obtained. In these studies all measurements of parietal cell antibody titer were carried out with a single pool of fluoresceinated antiserum to $\gamma \mathrm{G}$ globulin; thus the titers measured in different pernicious anemia sera reflect variations in the concentration of parietal cell antibody alone. These titers are slightly higher than those reported by Irvine and his associates $(8,14)$, who used a complement fixation test with saline extracts of human gastric mucosa as antigen.

Taylor and co-workers (2) reported that the incidence of gastric antibodies in sera from patients with pernicious anemia was not related to the duration of disease. In the present study we have shown that the titer of parietal cell antibody is also unrelated to the duration of pernicious anemia; this confirms recent observations made by Irvine and associates, (14). In some patients there were high titers of serum antibody 20 to 25 years after the diagnosis of pernicious anemia had been established, whereas in other patients no antibody was detected in serum obtained at the time of diagnosis. Furthermore, serum samples obtained from individual patients during a period of 4 years showed no variation in antibody titer. 

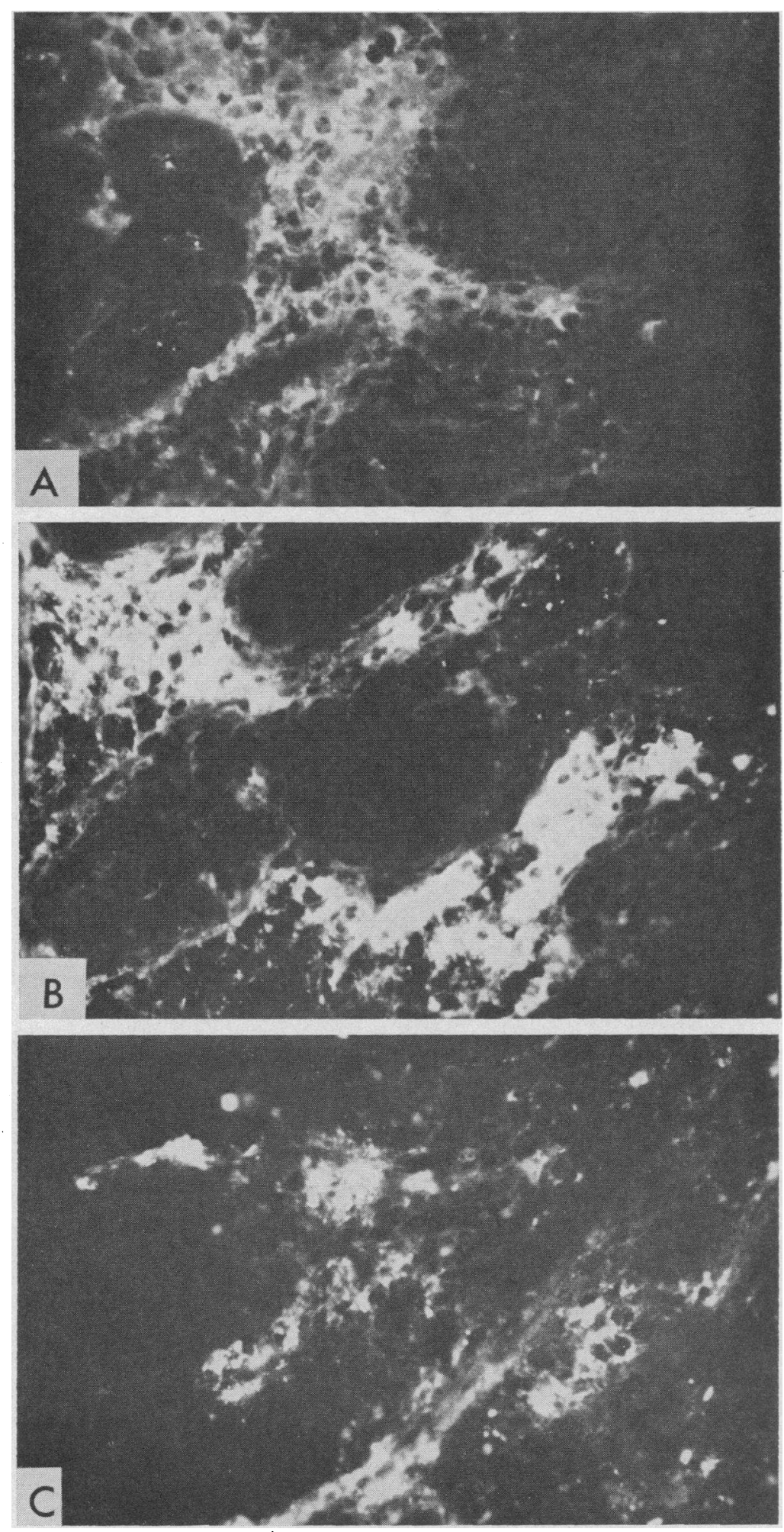

Fig. 5. The DISTRIBUtion OF IMMUNOGLOBULINS IN FROZEN SECTIONS OF A GASTRIC MUCOSAL BIOPSY FROM A PATIENT WITH PERNicious ANEMIA. Ace- 
In patients with adult pernicious anemia, gastric mucosal atrophy precedes the development of vita$\min B_{12}$ deficiency. If gastric mucosal atrophy results from a loss of the mucosal potential to regenerate parietal cells, there should be no further stimulation of parietal cell antibody production by mucosal antigen so that the titer of circulating parietal cell antibody should diminish progressively with time. The observation that the titer of parietal cell antibody does not change with time suggests that in many patients there is a continuous stimulation of antibody production. This may result from continuing regeneration and destruction of parietal cell precursors in the atrophic gastric mucosa. That this mucosa may retain its potential to regenerate parietal cells is indicated by the histologic and secretory changes that have been observed during prednisolone therapy $(10,11)$. The absence of parietal cell antibody in serum from some patients with pernicious anemia is not explained by this hypothesis. It is possible, however, that these patients have indeed lost the potential to regenerate gastric parietal cells; this might occur with extensive replacement of the mucosa in the body and fundus of the stomach by intestinal- or pyloric-type epithelium.

Parietal cell antibody, present in both serum and gastric juice, was identified as a $\gamma \mathrm{G}$-globulin. The presence of this antibody in gastric juice from patients with pernicious anemia has been confirmed independently by Fisher and Taylor (21). The low titer of antibody in gastric juice as compared with serum may result from a transudation of plasma across the mucosa; plasma proteins, including the immunoglobulins, have been identified previously in gastric juice (22-24). The possibility that parietal cell antibody is selectively secreted by the mucosa cannot be excluded, however, as the absolute concentrations of $\gamma \mathrm{G}$-globulin in serum and gastric juice were not measured.

Sera from patients with pernicious anemia may also contain antibodies that react with gastric intrinsic factor (3-6). This antibody has not been detected in gastric juice (20); nevertheless, it may be present in low concentrations sufficient to in- hibit the biologic activity of small amounts of intrinsic factor that may be secreted.

Mononuclear cells containing each of the immunoglobulins were identified in the lamina propria of gastric mucosal biopsies from patients with pernicious anemia. There is no evidence, however, that these cells produce antibodies that react with mucosal cell antigens. No parietal cell antibody could be detected in buffered saline extracts of gastric mucosal biopsies. This negative observation does not exclude the presence of parietal cell antibody either in the interstitial lymph or in mononuclear cells in the lamina propria; the concentration of antibody in the saline extracts may have been too low to be detected in the immunofluorescent test.

\section{Summary}

1) Parietal cell antibody was detected by an immunofluorescent method in sera from 62 of 72 patients $(86 \%)$ with adult pernicious anemia. The titer of parietal cell antibody in the serum was not related to the duration of the patient's pernicious anemia and did not vary in individual patients over a period of up to 4 years.

2) Parietal cell antibody was present in the $\gamma \mathrm{G}$-globulin fraction of serum; it was either absent or present in very low titers in the $\gamma \mathrm{A}$-globulin fraction, and it was not detected in the $\gamma \mathrm{M}$-globulin fraction.

3) Parietal cell antibody was demonstrated in gastric juice from patients with pernicious anemia. It was present in the $\gamma \mathrm{G}$-globulin fraction, and its titer in the juice was considerably lower than that in the patient's serum.

4) Immunoglobulins were present in the mononuclear cells in the lamina propria of the gastric mucosa from patients with pernicious anemia. Parietal cell antibody could not be detected in mucosal extracts.

\section{References}

1. Jeffries, G. H., and M. H. Sleisenger. Immunofluorescent studies in pernicious anemia (abstract). Gastroenterology 1965, 48, 823.

2. Taylor, K. B., I. M. Roitt, D. Doniach, K. G. Couchman, and C. Shapland. Autoimmune phenomena in

tone-fixed sections of gastric mucosa from a patient with pernicious anemia were incubated with fluoresceinated antisera to $\gamma \mathrm{G}$-globulin (A), $\gamma \mathrm{A}$-globulin (B), and $\gamma \mathrm{M}$-globulin (C). Fluorescence is concentrated in mononuclear cells in the lamina propria. 
pernicious anaemia. Gastric antibodies. Brit. med. J. 1962, 2, 1347.

3. Taylor, K. B. Inhibition of intrinsic factor by pernicious anæmia serum. Lancet 1959, 2, 106.

4. Schwartz, M. Intrinsic factor antibody in serum from patients with pernicious anaemia. Lancet 1960, 2, 1263.

5. Jeffries, G. H., D. W. Hoskins, and M. H. Sleisenger. Antibody to intrinsic factor in serum from patients with pernicious anemia. J. clin. Invest. 1962, 41, 1106.

6. Abels, J., W. Bouma, A. Jansz, M. G. Woldring, A. Bakker, and H. O. Nieweg. Experiments on intrinsic factor antibody in serum from patients with pernicious anemia. J. Lab. clin. Med. 1963, 61, 893.

7. Irvine, W. J., S. H. Davies, I. W. Delamore, and A. W. Williams. Immunological relationship between pernicious anaemia and thyroid disease. Brit. med. J. 1962, 2, 454.

8. Irvine, W. J. Gastric antibodies studied by fluorescence microscopy. Quart. J. exp. Physiol. 1963, 48, 427.

9. Markson, J. L., and J. M. Moore. Autoimmunity in pernicious anaemia and iron-deficiency anæmia: a complement-fixation test using human gastric mucosa. Lancet 1962, 2, 1240.

10. Jeffries, G. H. Recovery of gastric mucosal structure and function in pernicious anemia during prednisolone therapy. Gastroenterology 1965, 48, 371.

11. Jeffries, G. H., J. E. Todd, and M. H. Sleisenger. Pernicious anemia. The effect of prednisolone on gastric mucosal histology, gastric secretion, and vitamin $\mathrm{B}_{12}$ absorption. Submitted for publication.

12. Thomas, L. Circulating autoantibodies and human disease; with a note on primary atypical pneumonia. New Engl. J. Med. 1964, 270, 1157.

13. Herbert, V., R. R. Streiff, and L. W. Sullivan. Notes on vitamin $\mathrm{B}_{12}$ absorption: autoimmunity and childhood pernicious anemia; relation of intrinsic fac- tor to blood group substance. Medicine (Baltimore) 1964, 43, 679.

14. Irvine, W. J., S. H. Davies, S. Teitelbaum, I. W. Delamore, and A. W. Williams. The clinical and pathological significance of gastric parietal cell antibody. Ann. N. Y. Acad. Sci. 1965, 124, 657.

15. Kay, A. W. Effect of large doses of histamine on gastric secretion of $\mathrm{HCl}$; an augmented histamine test. Brit. med. J. 1953, $2,77$.

16. Flick, A. L., W. E. Quinton, and C. E. Rubin. A peroral hydraulic biopsy tube for multiple sampling at any level of the gastrointestinal tract. Gastroenterology 1961, 40, 120.

17. Burkholder, P. M., A. H. Littell, and P. G. Klein. Sectioning at room temperature of unfixed tissues, frozen in a gelatin matrix, for immunohistologic procedures. Stain Technol. 1961, 36, 89.

18. Rubin, W., A. S. Fauci, M. H. Sleisenger, and G. H. Jeffries. Immunofluorescent studies in adult celiac disease. J. clin. Invest. 1965, 44, 475.

19. Te Velde, K., J. Abels, G. J. P. A. Anders, A. Arends, $\mathrm{Ph}$. J. Hoedemaeker, and H. O. Nieweg. A family study of pernicious anemia by an immunologic method. J. Lab. clin. Med. 1964, 64, 177.

20. Fisher, J. M., and K. B. Taylor. A comparison of autoimmune phenomena in pernicious anemia and chronic atrophic gastritis. New Engl. J. Med. 1965, 272, 499.

21. Fisher, J. M., and K. B. Taylor. Personal communication.

22. Heiskell, C. L., T. Wada, S. J. Stempien, M. Fukuda, S. Nakagawa, A. Yachi, A. Dagradi, and C. M. Carpenter. Normal serum proteins in gastric juice. A preliminary report. Gastroenterology 1961, 40, 775.

23. Tenorová, M., E. Stuchlíková, and J. Kořínek. Agarophoresis and immuno-electrophoresis of the proteins of gastric juice. Nature (Lond.) 1961, 192, 763.

24. Hurlimann, J. Les protéines du suc gastrique. Etude immunoélectrophorétique. Helv. med. Acta 1963, 30, 126. 